\title{
British continuing medical education: a framework for the future*
}

\author{
David Tait
}

This is the kind of conference at which the Royal Society of Medicine excels - an international array of speakers, firm chairmanship, time and space to meet other delegates, abstracts published with the programme and a Consensus Overview published within a fortnight (by Professor Hugh Freeman as rapporteur).

The conference took place in the context of the Chief Medical Officer's consultation paper for his conference on 13 June 1994. A sister working paper from the Standing Committee on Postgraduate Medical and Dental Education was published and tabled during the conference. Our College's ideas are also reaching maturity and were recently summarised (Sims, 1994).

I remain unconvinced that the public demands, or that governments will impose, continuing medical education, but I accept that with reluctance of career grade staff to use their study leave entitlement, and reluctance of their trusts to fund it, an elaborate scheme originating from the profession is both inevitable and desirable.

We were informed of a variety of ways how this might be done. In Canada the ambitious Maintenance of Competence Programme is underway based upon a personal diary system, which, when PC-based, allows the participant to compare his CME activity with that of his peers also submitting their learning activity and its outcome to a central databank.

Furthest down the line are the Royal Australian College of Obstetricians and Gynaecologists who have now completed a first cycle of $\mathrm{CME}$ and are facing the challenge of how to respond to those (few)

-Conference held at the Royal Society of Medicine. 15/16 September 1994. practitioners who have failed to meet their criteria, and thereby lose their Fellowship.

Closer to home the European Union of Medical Specialists acts as the umbrella organisation striving for consensus among doctors from member states.

The questions of funding and control are inextricably linked - the individual may seek education or continuing professional development in its broadest sense in the belief that remaining alert and questioning is as important for maintaining standards as the acquisition of specific skills. By contrast her employer may see CME more in terms of equipping her to better deliver contracted services or market new ones, purchasers' agendas may differ again with their seeking to match their perception of need with the present or potential skill of their providers.

It came as no surprise that the most thorough measure of individual practice rests with BUPA (British United Provident Association) - their interest being in costs and treatment profiles, but also potentially serving a second role in defining the need or scope of CME of its specialists.

The way forward will include contributions from Postgraduate Deans and the Universities, and the Department of Health remain closely involved. Most helpful, however, may be the exploitation of the remarkable degree of consensus which exists among the medical royal colleges to which our own College, and Professor Andrew Sims in particular, have made a major contribution.

\section{Reference \\ Sims. A. (1994) Introducing continuing professional development. Advances in Psychiatric Treatment, 1, 3-8.}

David Tait, Consultant Psychiatrist, Murray Royal Hospital, Perth PH2 7BH 